\title{
Overdenture treatment in patient with severely worn dentition: a case report
}

\author{
Min-Ji Kim, Jun-Yub Kim, Hong-So Yang, Hyun-Pil Lim, Kwi-Dug Yun, Chan Park, Jin-Ho Shin, \\ Sang-Won Park* \\ Department of Prosthodontics, School of Dentistry, Chonnam National University, Gwangju, Republic of Korea
}

Overdenture is one of the methods of patients with severely worn dentition. Remaining natural teeth help preserve alveolar bone and proprioception and provide rigid support. Also, overdenture distributes the concentrated stress applied to the abutment tooth and denture supporting tissues. There is an advantage that it can provide long-term stability to denture. In this case, the patient with only a few teeth due to severe wear and caries was satisfied with good function and favorable esthetics by using overdenture. (J Dent Rehabil Appl Sci 2016;32(4):307-13)

Key words: worn dentition; overdenture

\section{서론}

마모가 일어나게 되면 법랑질층의 부재로 인해 상아질 의 빠른 마모현상이 일어나게 되며 이로 인해 치수조직의 노출이 일어날 수 있으며 근관치료의 적응증이 될 수 있 다. 이 때문에 심한 마모를 보이는 환자에서 자연치를 금 속으로 코핑하여 피개의치를 제작하는 방법은 치질의 유 지및 수직고경 회복을 가능하게 하므로 하나의 치료 방 법이 될 수 있다. ${ }^{1}$

피개의치를 위한 지대치 형성 방법으로는 부가 유지력 을 위한 어태치먼트를 장착하는 것과 잔존치조제의 유지 를 위해 지대치에 코핑 보철물을 하거나, 단순 충전하는 방법이 있다. ${ }^{2,3}$ 피개의치 유지장치를 이용하는 방법은 부 가적인 유지를 제공한다는 장점은 있지만 비용이 증가하 는 것은 물론 기술적 요구도와 합병증 발생으로 인해 수 리가 요구될 수 있다는 단점이 있다. 지대치를 코핑하거 나 단순 충전하여 이용하는 방법은 부가적인 유지를 제

*Correspondence to: Sang-Won Park Associate Professor, Department of Prosthodontics, School of Dentistry, Chonnam National University, 33 Yongbong-ro, Buk-gu, Gwangju, 61186, Republic of Korea

Tel: +82-62-530-5631, Fax: +82-62-530-5639, E-mail: psw320@jnu.ac.kr

Received:October 4, 2016/Last Revision: October 24, 2016/Accepted: November 22,2016
공할 수는 없다는 단점이 있으나 안정감을 제공하며 유 지장치를 사용하는 방법에 비해 비용이 저렴하고 기술적 요구도가 적다는 장점이 있다. ${ }^{4}$

본 증례의 환자는 심한 마모와 우식으로 인해 소수 건 전치를 가진 환자로 짧은 치관을 가졌으나 그에 비해 충 분한 치조골과 건전한 치근을 가져 추가적인 유지를 필 요로 하지 않았다. 그로 인해 상, 하악 소수 건전치를 금 코핑을 이용하여 피개의치로 수복한 증례이다.

\section{증례 보고}

본 증례의 환자는 60 세 여환으로 틀니 상담을 원한 다는 주소로 내원하였다. 환자는 전신질환과 악관절 질 환 등 특이적인 병력은 없었다. 구내 검사에서 다수 치아 에 심한 마모로 인해 치아의 치관이 매우 짧은 상태였다. \#17, 24, 27, 31, 32, 46은 깊은 치은 연하 우식으로, \#14, 41,42 은 깊은 치주낭과 3 이상의 동요도를 보여 예후가

Copyright@ 2016 The Korean Academy of Stomatognathic Function and Occlusion. (c) It is identical to Creative Commons Non-Commercial License. 
불량하였다(Fig. 1). 그 외 방사선 분석 결과 특이한 소견 은 보이지 않았다(Fig. 2).

연구모형을 제작하여 수직고경을 분석하였다. 자유 공 극은 약 $10-11 \mathrm{~mm}$, 전정간 거리는 $30 \mathrm{~mm}$, 상악 전치부 길이는 $3-4 \mathrm{~mm}$, 하악 전치부 길이는 $1-2 \mathrm{~mm}$, 마모양 상은 병적이였으며 구치부 지지는 존재하지 않았다. 안 모평가에서도 짧은 하안모와 깊은 비순구 주름을 보였 다. Turner의 분류에 따르면 분류I로 감소된 수직고경의 회복이 필요하다고 판단되었다. ${ }^{5}$

환자에게 치료방법으로 임플란트 지지 가철성 또는 고 정성 보철, 국소의치, 피개의치에 대한 설명하고 상담 진
행하였으나 환자의 경제적 사정상 수리가 용이하고 비교 적 비용이 저렴한 피개의치 치료 방법을 선택하게 되었 다. 예후가 불량한 치아 및 상순의 과도한 풍융함을 방지 하기 위해 상악 전치부의 전략적 발치를 시행하고, 피개 의치의 지대치로서 $\# 13,23,33,35,43,45$ 의 치아를 잔 존시켰다. 환자의 치조능이 충분한 유지를 얻을 수 있는 상태이므로 지대치들은 금 코핑을 이용하기로 하였다.

고딕아치(gothic arch, Kuwoteck, Gwangju, Korea)를 통해 중심위로 유도하여 수평악간 관계를 채득하였고, 생리적 안정위, 발음, 연하, 환자가 느끼는 편안함을 종합 적으로 판단하여 적절한 수직고경을 설정하였다(Fig. 3).
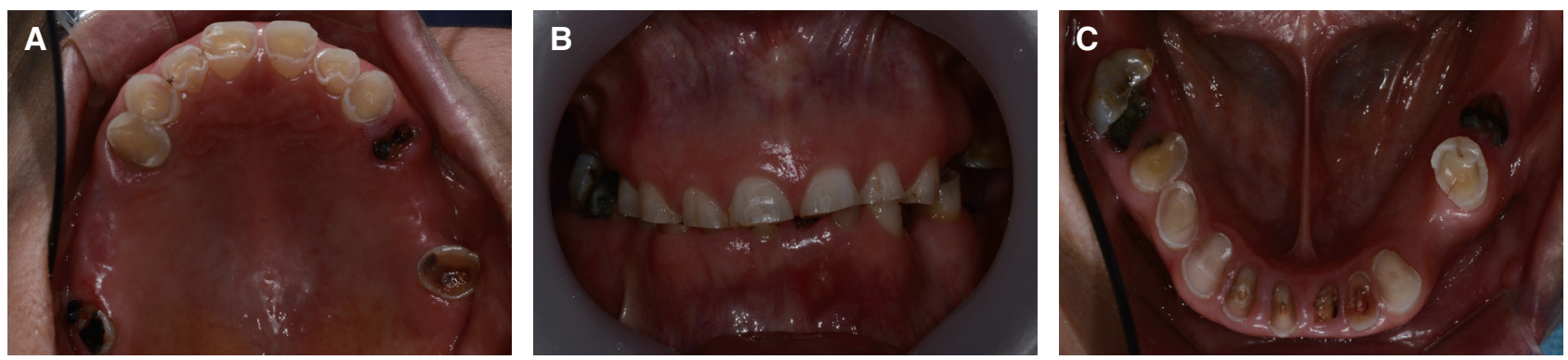

Fig. 1. Initial intraoral photographs. (A) Maxillary occlusal view, (B) Frontal view, (C) Mandibular occlusal view.

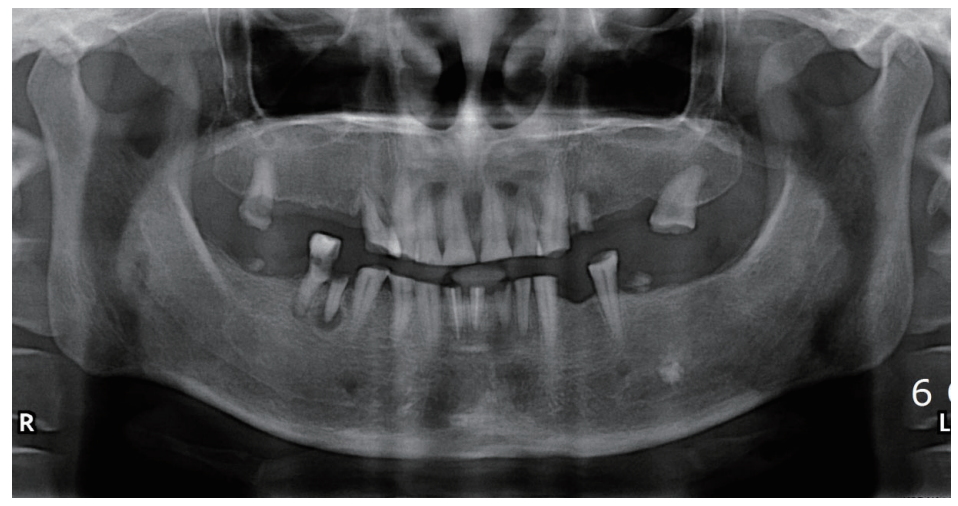

Fig. 2. Initial panoramic radiography.
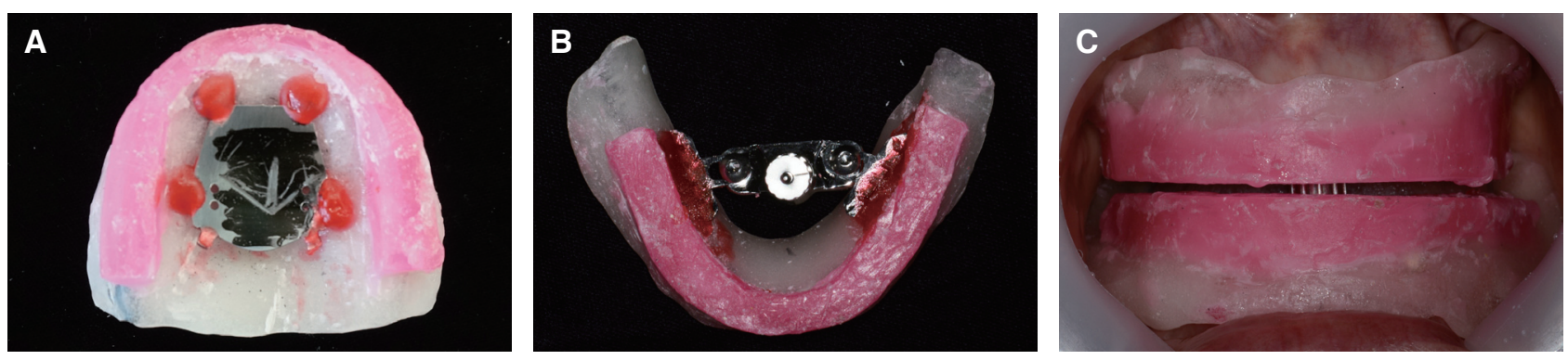

Fig. 3. (A) Maxillary occlusion rim with gothic arch tracer, (B) Mandibular occlusion rim with gothic arch tracer, (C) Maxillomandibular relationship taking with gothic arch tracer. 
채득한 악간 관계로 임시의치 제작하여 3 개월 간 착용하 게 하였다(Fig. 4). 적응기간 동안 악관절 문제나 근신경 계 문제는 보이지 않고 회복된 수직고경에 잘 적응한 모 습을 보였다. 환자는 기능적, 심미적으로 만족하였고 특 이할 만한 문제는 발견되지 않았다.

근관치료가 완료된 \#13, 23, 33, 35, 43, 45 지대치에 금 코핑제작을 위한 치아삭제를 행하였으며 폴리비닐 실록산 인상재(Honigum, DMG, Hamburg, Germany) 를 사용하여 인상채득하였다(Fig. 5). 제작된 금 코핑을
치아에 시적 후 레진 접착제(Rely X luting cement, 3M ESPE, St. Paul, USA)를 사용하여 접착하였다(Fig. 6).

개인트레이의 제작을 위해 상, 하악 예비인상을 채득 하였다. 연구모형에서 개인트레이를 제작하여 변연형성 후 폴리설파이드 인상재(Permlastic, Kerr Manufacturing $\mathrm{co}$, Romulus, USA)를 사용하여 최종 인상채득하였다 (Fig. 7). 금속프레임과 교합제를 평균적인 규격에 따라 제작하였으며 임시의치의 상, 하악 악간 관계를 이용해 수직 위, 수평 위를 교합기에 이전하였다(Fig. 8).
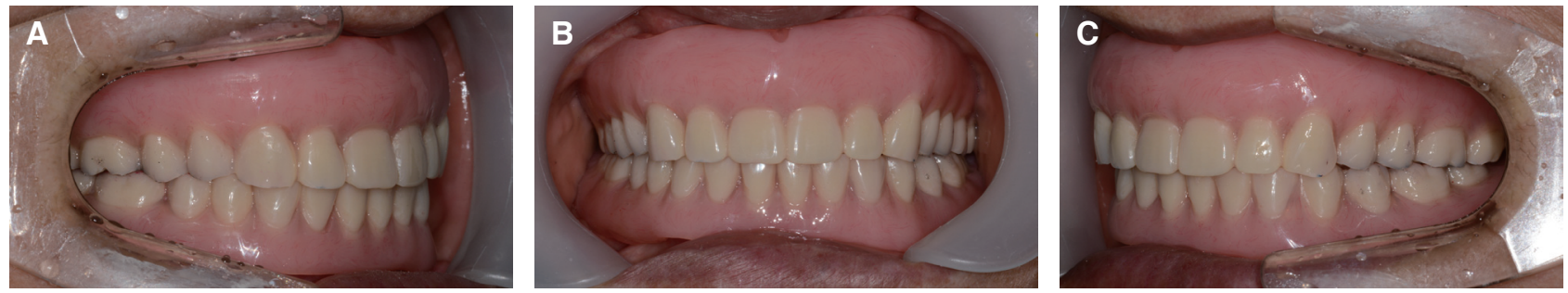

Fig. 4. Provisional prosthesis. (A) Lateral view (right), (B) Frontal view, (C) Lateral view (left).
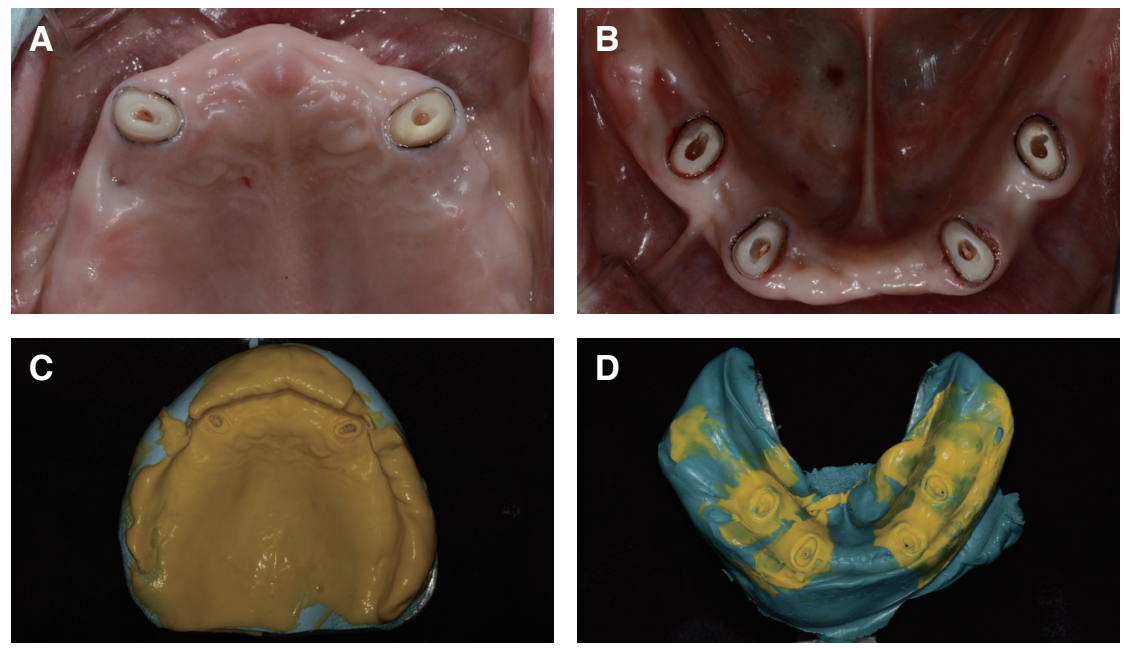

Fig. 5. (A) Preparation for gold coping on maxillary teeth, (B) Preparation for gold coping on mandibular teeth, (C) Definitive impression taking of maxilla, (D) Definitive impression taking of mandible.
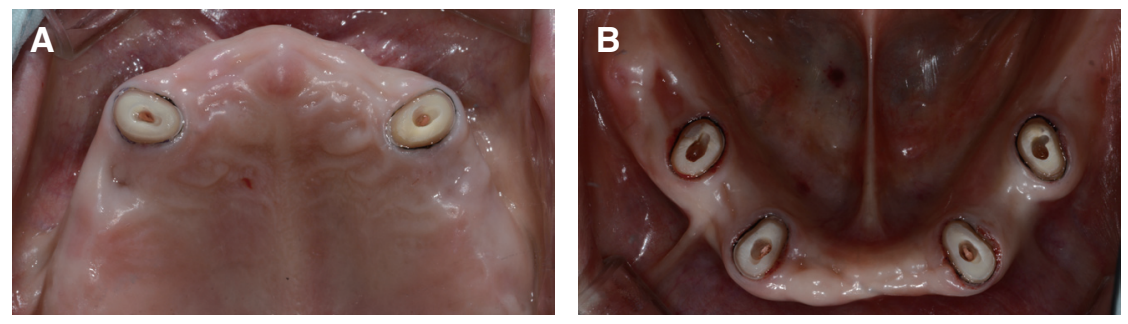

Fig. 6. (A) Installed gold coping with resin cement on maxilla, (B) Installed gold coping with resin cement on mandible. 

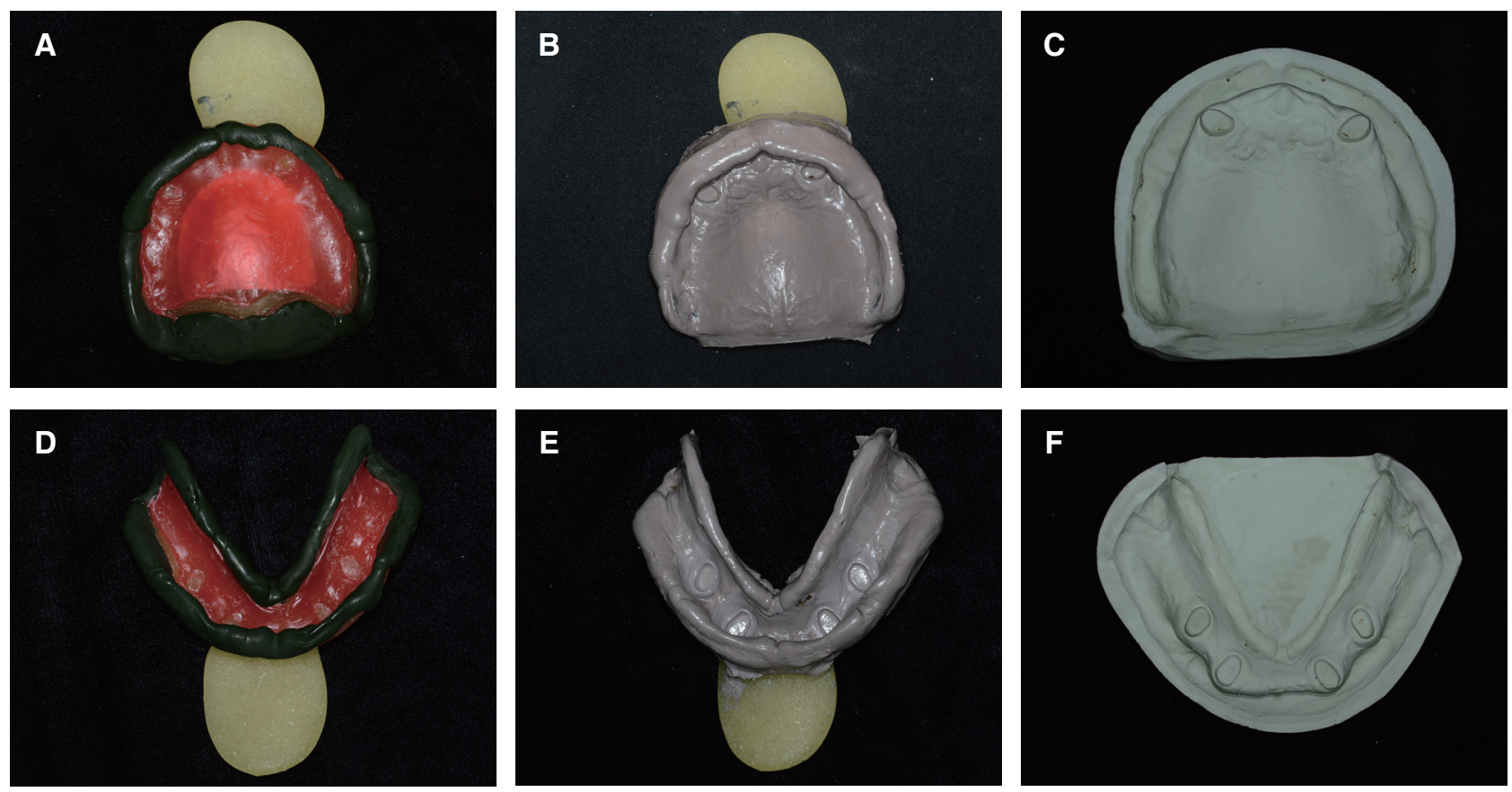

Fig. 7. Bordermolding and definitive impression taking. (A) Bordermolding for maxillary denture, (B) Final impression of maxilla, (C) Master cast of maxilla, (D) Bordermolding for mandibular denture, (E) Final impression of mandible, (F) Master cast of mandible.
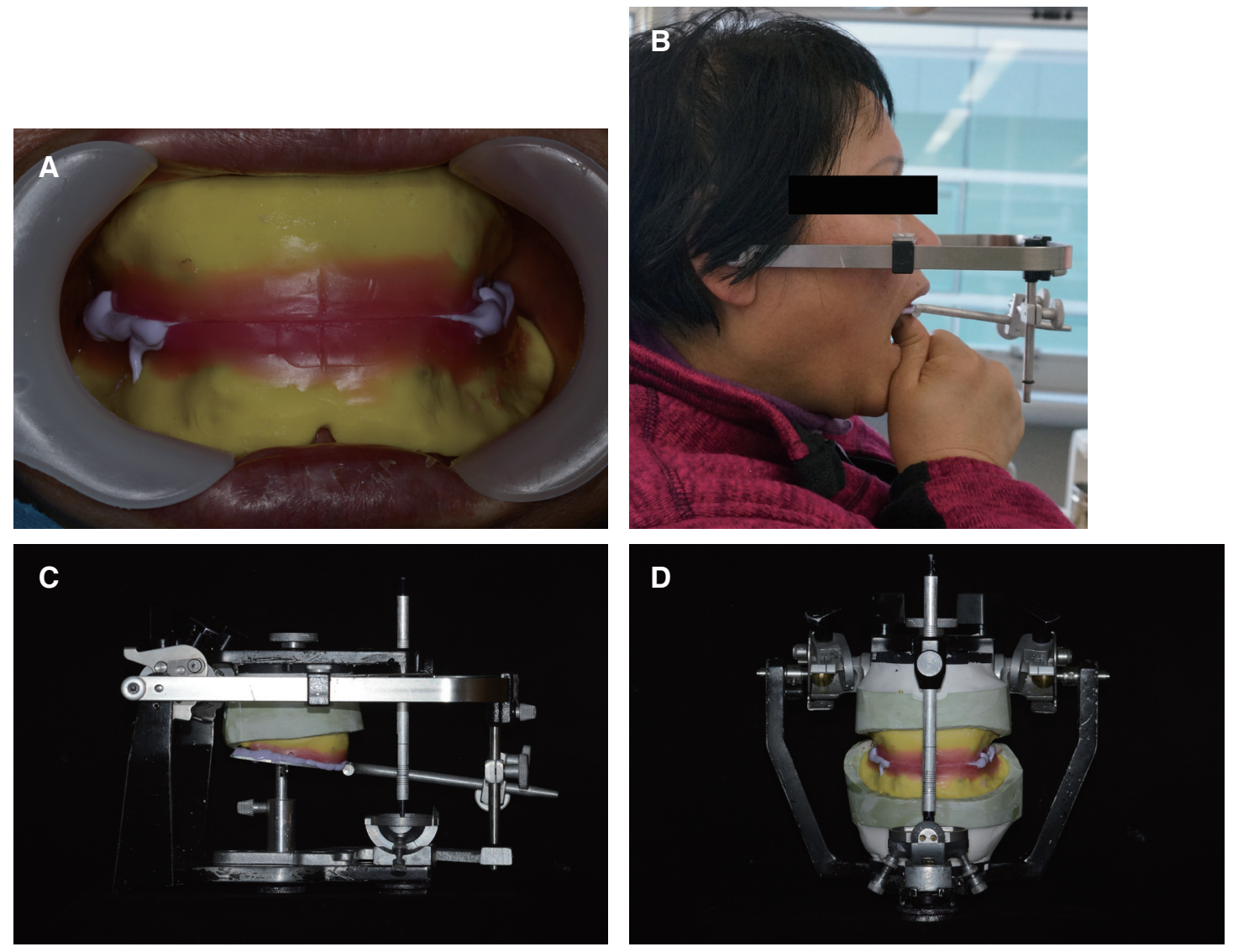

Fig. 8. (A) Maxillomandibular relationship registration, (B) Facebow transfer, (C, D) Mounting procedure to semiadjustable articulator. 
인공치아를 배열하여 양측성 균형교합을 부여하였다. 납의치를 구강 내에 시적 하였고, 환자는 치아 형태 및 배 열에 만족하여 온성을 시행하였다(Fig. 9). 그 후 기공실 재부착, 임상적 재부착을 통해 미세한 교합조정을 실시 하여 양측성 균형교합을 부여하였으며 의치내면 조절에 있어서는 코핑의 상부만 의치내면에 닿도록 조정하여 의 치의 지지를 얻으면서도 고른 응력분산을 하도록 하여 구내 장착하였다(Fig. 10).
술 후 방사선 영상에서 특이한 병적 변화는 관찰되지 않았으며 치료 이후 6 개월 관찰 결과 기능적, 심미적으로 만족할 만한 결과를 얻었다(Fig. 11).

\section{고찰}

본 증례에서는 심한 마모를 가지고 있으며 우식으로 인해 소수 건전치를 가진 환자에게 상, 하악 금 코핑을 이
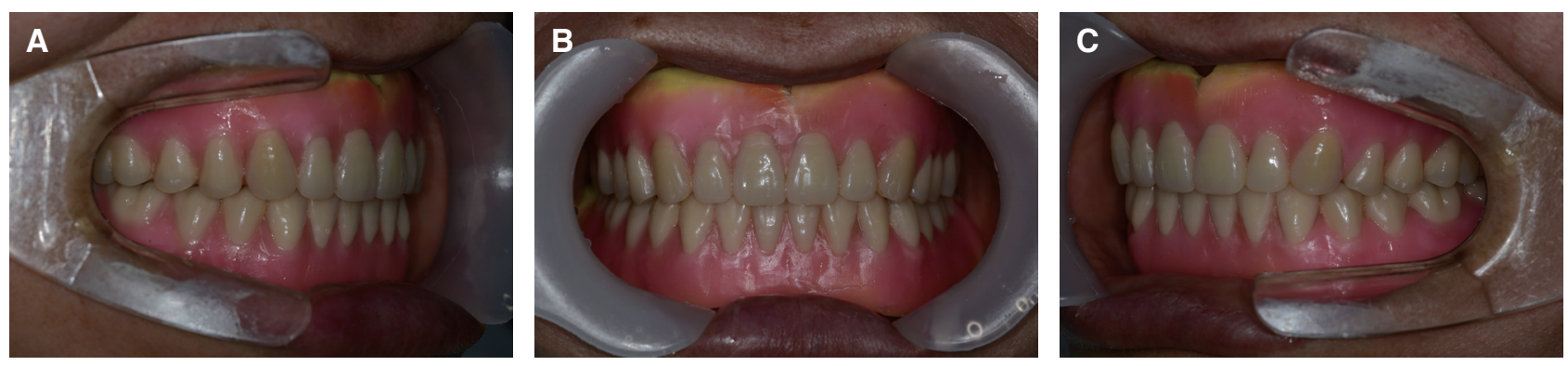

Fig. 9. Wax denture try-in. (A) Lateral view (right), (B) Frontal view, (C) Lateral view (left).
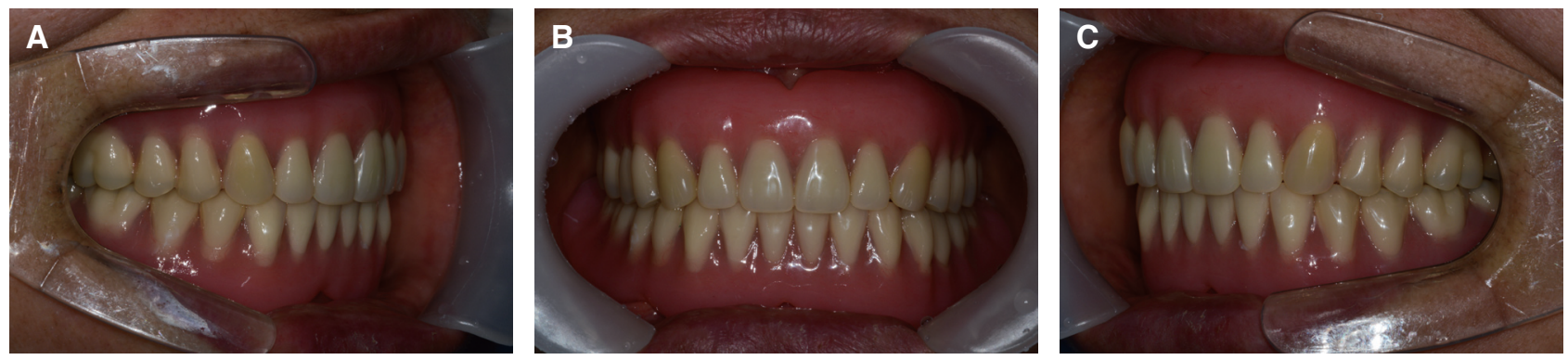

Fig. 10. Definitive denture. (A) Lateral view (right), (B) Frontal view, (C) Lateral view (left).
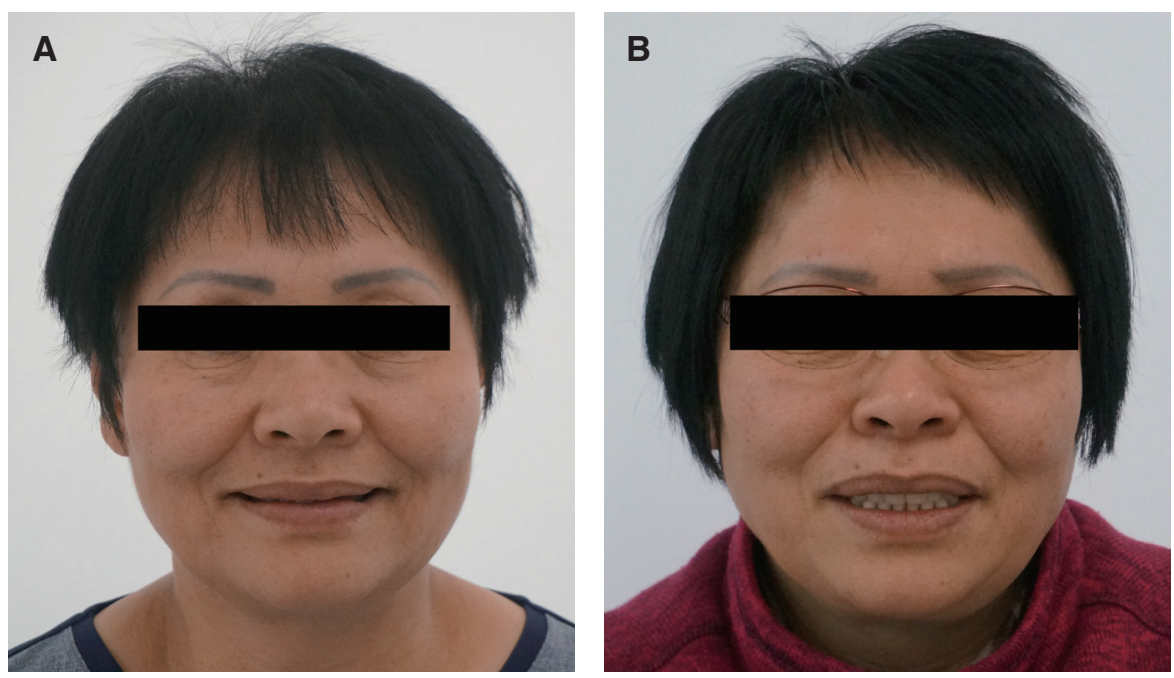

Fig. 11. Patient's profile. (A) Profile of first visit, (B) Profile of after definitive denture delivery. 
용한 자연치 피개의치를 제작하여 기능적, 심미적으로 만 족스러운 결과를 얻었다.

본 증례는 건전치의 치아 및 주위 연조직 보존과 마모 로 인한 수직고경 재형성 그리고 높은 우식이환율에 대 한 고려가 필요한 증례였다. 자연치를 이용한 피개의치 는 안정감을 줄 수 있고, 치조골이 보존되는 장점 외에도 자연치에 의한 지지점의 제공으로 지지가 증가한다는 장 점이 있기 때문에 치근이 건전한 본 증례에 자연치를 이 용한 피개의치는 좋은 적응증이였다. ${ }^{4}$

Turner와 Missirlian은 구치부 지지, 마모여부, 발음, 악간 거리 평가 및 안모를 고려하여 수직고경 평가를 시행해야 한다고 하였다. ${ }^{5}$ 본 증례의 환자는 평가를 통해 약 $8 \mathrm{~mm}$ 수직고경 회복이 필요하다고 사료되어 임시 의치 상태로 약 8주간 관찰하였으며 환자의 적응 여부를 판단하였다.

하지만 자연치 피개의치에서 생각해야 할 문제점 중 하 나는 우식이다. ${ }^{6}$ 지대치는 의치에 의해 폐쇄된 환경에 놓 여 있기 때문에 타액 완충력이 감소되며, 치수에 가까운 상아질은 덜 광화되어 있어 더 다공성인 상아질이기 때문 에 우식에 취약하다. ${ }^{7,8}$ 본 환자의 경우 심한 마모가 존재 할 뿐더러 우식으로 인해 다수 치아가 발거한 기왕력이 있었기에 우식에 대한 고려가 필요하였다. 그러므로 우 식치료 및 방지의 한 방법으로 잔존치를 금속으로 피개 하여 피개의치를 제작하였다. ${ }^{9,10}$

자연치 피개의치 제작을 위한 코핑 디자인으로는 텔레 스코프 코핑, 돔 모양의 코핑이있다. 텔레스코프코핑의 경우 생활치를 그대로 사용할 수 있으며 수직 및 측방 변 위 등을 방지하는 안정을 제공할 수 있다는 장점이 있으 나, 상기 환자는 오랜 기간 마모로 인해 상악 전치부 길이 는 3-4 $\mathrm{mm}$, 하악 전치부 길이는 1-2 $\mathrm{mm}$ 로 매우 짧은 치관 길이를 가졌으며 심한 마모로 인해 지대치 모두 근 관치료의 적응증에 해당되었기 때문에 돔 모양의 코핑을 이용하였다. 돔 모양의 코핑은 의치상 만곡부에 큰 응력 이 집중되는 단점이 있으나, 지대치의 응력집중의 크기를 줄이며 텔레스코프 코핑보다는 지대치에 전달되는 응력 이 분산 지지된다는 장점이 있다. ${ }^{11}$

\section{결론}

최종 의치는 양측성 균형교합형성으로 안정적인 교합 접촉을 가질 수 있게 하였으며 현재 환자는 기능적, 심미 적으로 크게 만족하고 있다. 추후 장기적 안정성을 위해 지속적인 검진과 유지관리가 필요할 것이다.

\section{ORCID}

Min-Ji Kim http://orcid.org/0000-0002-3241-5214

Hong-So Yang http://orcid.org/0000-0002-9138-4817

Hyun-Pil Lim http://orcid.org/0000-0001-5586-1404

Kwi-Dug Yun http://orcid.org/0000-0002-2965-3967

Chan Park http://orcid.org/0000-0001-5729-5127

Sang-Won Park http://orcid.org/0000-0002-9376-9104

\section{References}

1. Licht WS, Leveton EE. Overdentures for treatment of severe attrition. J Prosthet Dent 1980;43:497500 .

2. Zamikoff II. Overdentures-theory and technique. J Am Dent Assoc 1973;86:853-7.

3. Basker RM, Harrison A, Ralph JP. Overdentures in general dental practice. Part 5-the use of copings and attachments. Br Dent J 1983;155:9-13.

4. Brewer AA, Morrow RM. Overdentures. $2^{\text {nd }}$ ed. St. Louis; Mosby; 1980. p. 4-10.

5. Turner KA, Missirlian DM. Restoration of the extremely worn dentition. J Prosthet Dent 1984;52: 467-74.

6. Ettinger RL, Jakobsen J. Caries: a problem is an overdenture population. Community Dent Oral Epidemiol 1990;18:42-5.

7. Garberoglio R, Brännström M. Scanning electron microscopic investigation of human dentinal tubules. Arch Oral Biol 1976;21:355-62.

8. Fosse G, Seale PK, Eide R. Numerical density and distributional pattern of dentine tubules. Acta Odontol Scand 1992;50:201-10.

9. Fenton AH. The decade of overdentures: 19701980. J Prosthet Dent 1998;79:31-6.

10. Lord JL, Teel S. The overdenture: patient selection, use of copings, and follow-up evaluation. J Prosthet Dent 1974;32:41-51.

11. Park HK, Chun CH, Cho KZ. Finite element analysis of mandibular stresses induced by overdenture with different designs of abutment copings. J Korean Acad Prosthodont 1991;29:141-70. 


\section{심한 마모를 보이는 환자에서의 자연치 피개의치 수복증례}

\section{김민지, 김준엽, 양홍서, 임현필, 윤귀덕, 박 찬, 신진호, 박상원*}

전남대학교 치의학전문대학원 보철학교실

심한 마모를 보이는 환자에서 자연치를 이용한 피개의치는 하나의 치료 방법이 될 수 있다. 자연치를 이용한 피개의치는 치조골의 보존, 감각수용기능의 유지를 가능하게 하며 강한 지지를 제공한다. 또한 지대치와 의치 지지조직에 가해지는 응력집중을 분산시키며, 의치에 의한 이차고정으로 장기간의 안정성을 제공해줄 수 있다는 장점이 있다. 본 증례는 심한 마모와 우식으로 인해 소수 건전치를 가지는 환자에서 자연치 피개의치를 이용하여 수복한 증례로 심미적, 기능적으로 만족스러운 결과를 얻었기에 보고하는 바이다.

(구강회복응용과학지 2016;32 (4):307-13)

주요어: 마모 치열; 피개의치 